Article

\title{
The Disappearance of Helike-Classical Greece-New Remote Sensing and Geological Evidence
}

\section{George Ferentinos ${ }^{\dagger}$, George Papatheodorou *, Maria Geraga ${ }^{\dagger}$, Dimitris Christodoulou ${ }^{\dagger}$, Elias Fakiris ${ }^{\dagger}$ and Margarita Iatrou ${ }^{\dagger}$}

Laboratory of Marine Geology and Physical Oceanography, Department of Geology, University of Patras, Patras 26504, Greece; E-Mails: gferen@upatras.gr (G.F.); mgeraga@upatras.gr (M.G.); dchristo@upatras.gr (D.C.); fakiris@upatras.gr (E.F.); iatroum@upatras.gr (M.I.)

$\dagger$ These authors contributed equally to this work.

* Author to whom correspondence should be addressed; E-Mail: gpapathe@upatras.gr; Tel./Fax: +30-2610-996-275.

Academic Editors: Rosa Lasaponara, Nicola Masini, Clement Atzberger and Prasad S. Thenkabail Received: 5 July 2014 / Accepted: 16 January 2015 / Published: 23 January 2015

\begin{abstract}
Helike, the Achaean Dodecapolis capital, in the Corinth Gulf, Greece, was, according to historical sources, devastated and disappeared from sight during an earthquake followed by sea invasion on to land in 373/372 B.C. A marine remote sensing survey, which was carried out to examine a landslide following a $6.2 \mathrm{R}$ earthquake in 1995, that affected the coastal and near-shore delta plain zone on which Helike stood, accompanied by onshore borehole data, enabled us to postulate the geological processes leading to the Helike catastrophe. Helike was initially leveled during a 6 to $6.7 \mathrm{R}$ earthquake; it is postulated to have then submerged following a translational landslide caused by liquefaction. This Helike catastrophe model is consistent with historical sources and current views regarding the expected geological hazards magnitude in the Gulf.
\end{abstract}

Keywords: Helike city; coastal/nearshore landslide; Corinth Gulf; side scan sonar; subbottom profiler 


\section{Introduction}

Helike, the capital of the "The Achaean Dodecapolis", was located on the southwestern shore of the Corinth Gulf (Greece), between the Selinountas and Kerynitis deltas (Figure 1), one of the most seismically active areas in the world [1]. Helike was devastated and then disappeared from the earth's surface during a winter's night in 372/373 B.C. (Aristotle, fourth century B.C.; Herakleides, fourth century B.C.; Diodoros, first century B.C.; Strabo, first century A.D.; Pausanias, second century A.D.; and Aelian, second century A.D.). For all available ancient sources, see Katsonopoulou [2]. For more than 500 years the ruins of Helike, as mentioned by Pausanias, were visible under water. Since the second century A.D., all traces of Helike have vanished. Many recent researchers have tried to unearth Helike and describe in modern scientific terms the geological processes behind the catastrophe [3-7]. In this paper, an attempt is made to shed light on the potential geological processes, which led to the disappearance of Helike from the earth's surface. This study is based on: (i) marine remote sensing and geological data collected during a geophysical/geotechnical survey, which was carried out at a coastal landslide, located between the Selinountas and Kerynitis rivers at a distance of between 1 and $1.5 \mathrm{~km}$ northwards from where the classical Helike city stood, and triggered by a $6.2 \mathrm{R}$ earthquake in 1995 [8-10] (Figures 1 and 2); (ii) recent geoarchaeological findings about Helike; and (iii) descriptions from historical sources of the events that caused the disappearance of Helike.

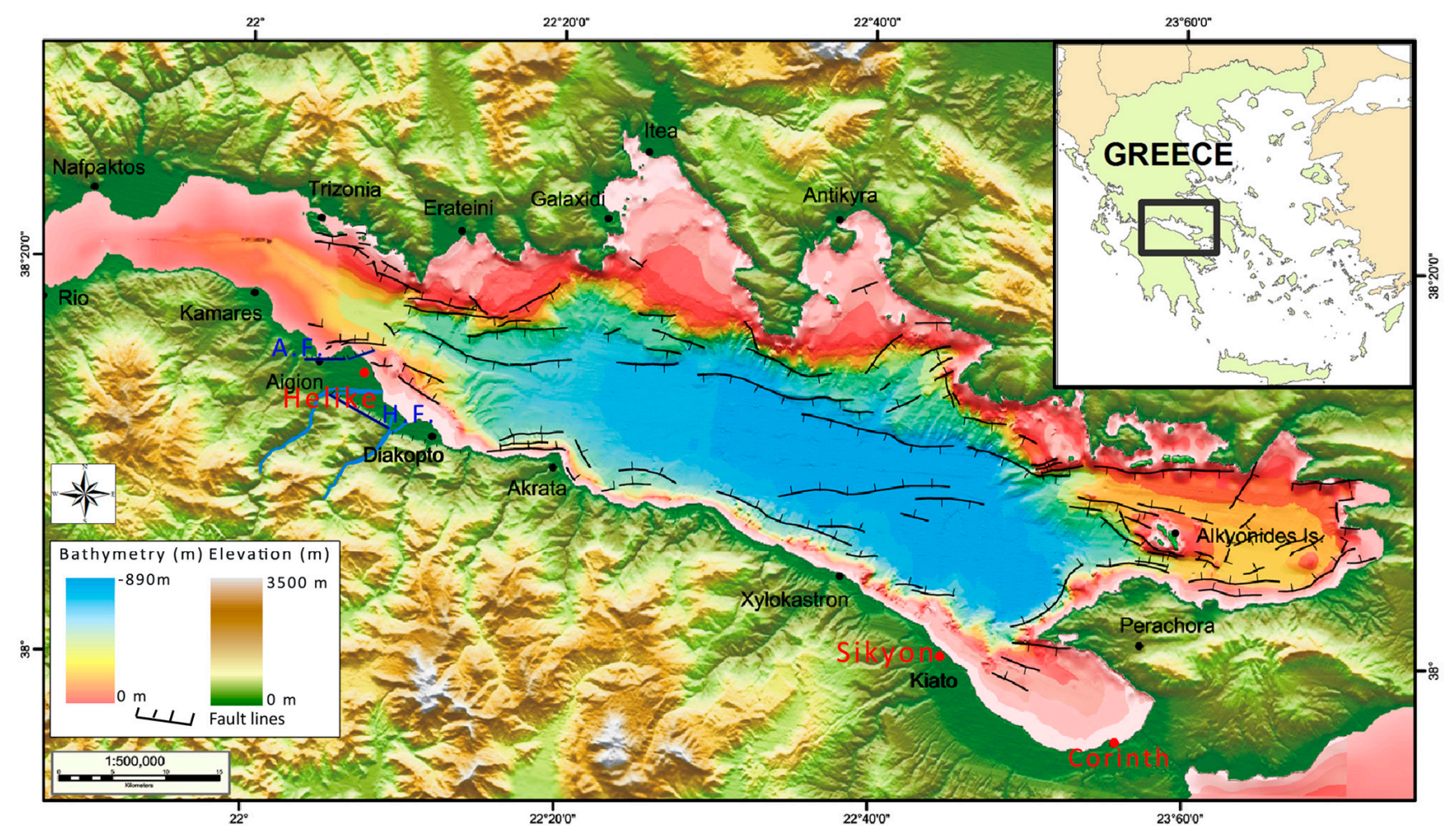

Figure 1. Digital terrain model of the Corinth Gulf showing the offshore and onshore active faults [8-10], the delta plain on which Helike was built, and the harbors of the major coastal cities of that time (Sikyon and Corinth). AF: Aegion and HF: Helike active faults. Inset: Map of Greece showing the study area. 


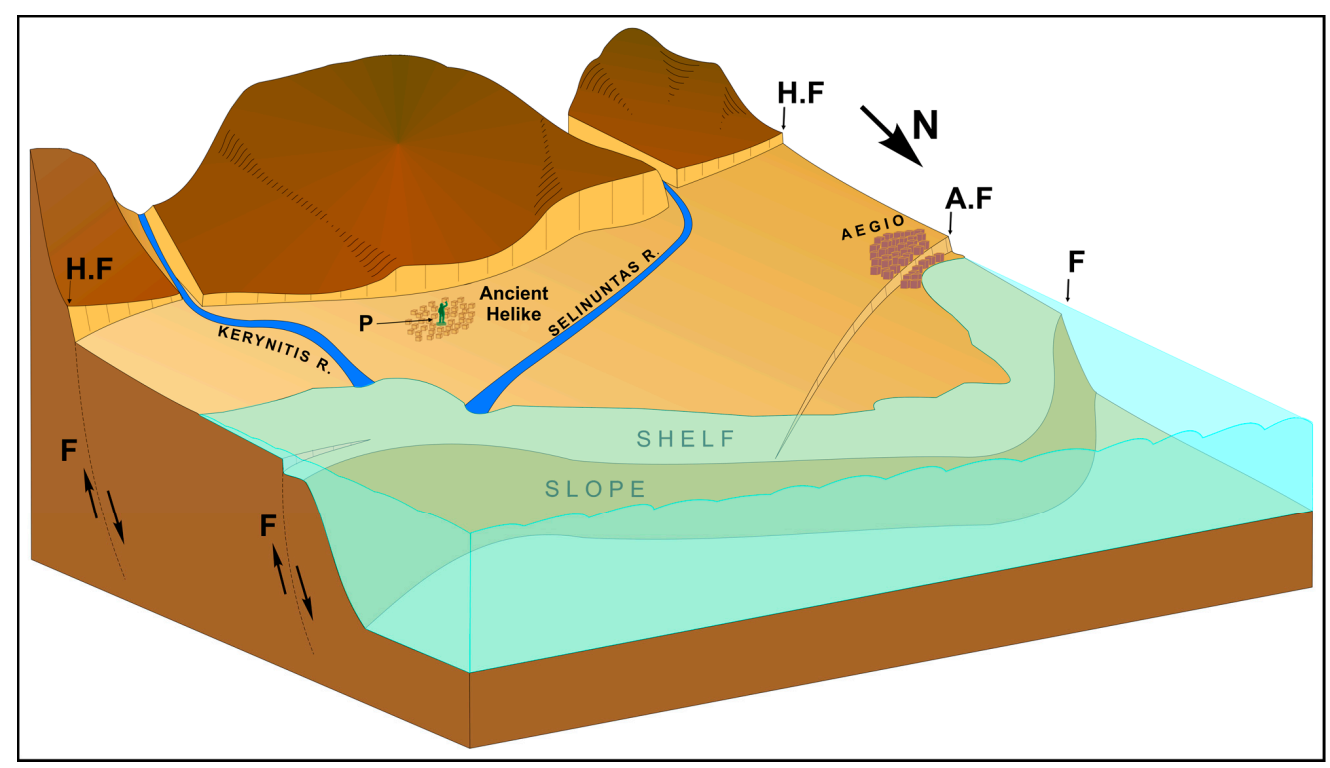

Figure 2. Three-dimensional morpho-tectonic sketch map (not in scale) of the Helike delta plain showing the location of ancient Helike city between the Helike (HF) and Aegion (AF) active faults. (P): Poseidon statue, (F): fault.

\section{Geographical-Geological Setting}

Helike city, according to Pausanias, was located on the southwestern coast of the Corinth Gulf, between the Selinountas and Kerynitis rivers (Figures 1 and 2). According to Heracleides, Helike was built on the delta plain formed by the above mentioned rivers at a distance of $2 \mathrm{~km}$ from the shoreline, near the foothills of the mountains to the south (Figure 2). The delta plain, on which Helike was built, developed on a tilted fault block bounded to the north and south by the Aigion and Helike active faults, respectively [8] (Figures 1 and 2).

A study of the historical sources [2] reveals that an earthquake was responsible for the devastation of Helike whilst sea invasion was responsible for its disappearance. Diodoros stated "there was first an earthquake during the night which devastated Helike and at dawn the sea rose for a long time very high, and a wave even higher covered everything and the inhabitants together with their land disappeared". Aelian stated, "an earthquake occurred at night, the city subsided, a large wave invaded and Helike disappeared". Pausanias mentioned "the sea invaded over the land and encircled the whole of Helike and covered the sacred grove of Poseidon so that only the tops of the trees were visible, then an earthquake was sent by God and the sea advanced over the land and a wave dragged down Helike with its people". Pausanias, who visited Helike 500 years later, also mentioned "the ruins of the city were still visible under the water and corroded by salt water". Strabo stated, in referring to: (a) Heracleides, who was living at the time of the disaster, "the sea was raised by an earthquake and it invaded the land and though Helike was $2 \mathrm{~km}$ from the sea, was covered by water" and (b) Heratosthenes, who visited Helike 150 years after the disaster, "the ferryman told him that there was a bronze statue of Poseidon in an upright position in the strait, which was dangerous for those who were fishing with nets".

Recent archaeological excavations have shown the presence of traces of classical Helike covered by sediments at a depth of between 2.5 and $4 \mathrm{~m}$ below surface, and at a distance of between 1.0 and $1.5 \mathrm{~km}$ from the present day shoreline [2,6,7], in the location suggested by the abovementioned 
historians/geographers. The traces are covered by a veneer of lagoonal origin sediments [11,12], which suggests that Helike was covered by water for a long period of time.

\section{Methods of Study}

For the study of the geometry, structure and style of movement of the coastal landslide triggered by the 1995 earthquake, a marine remote sensing survey was carried out fifteen days after the earthquake (July 1995), and the geotechnical conditions prevailing in the sedimentary cover were examined.

\subsection{Marine Remote Sensing Survey}

A dense grid of seismic profiling and sonar imaging of the seafloor was carried out using a $3.5 \mathrm{kHz}$ subbottom seismic system with Geopulse transmitter and a 4 array transducer, and an E.G. \& G. Model 272-TD side scan sonar tow fish in association with an EG \& G Model 260 processor. The collected data were used for the 3D presentation of the landslides (Figure 3). Positioning and navigation was taken using a Magna-Vox MX200 global positioning system.

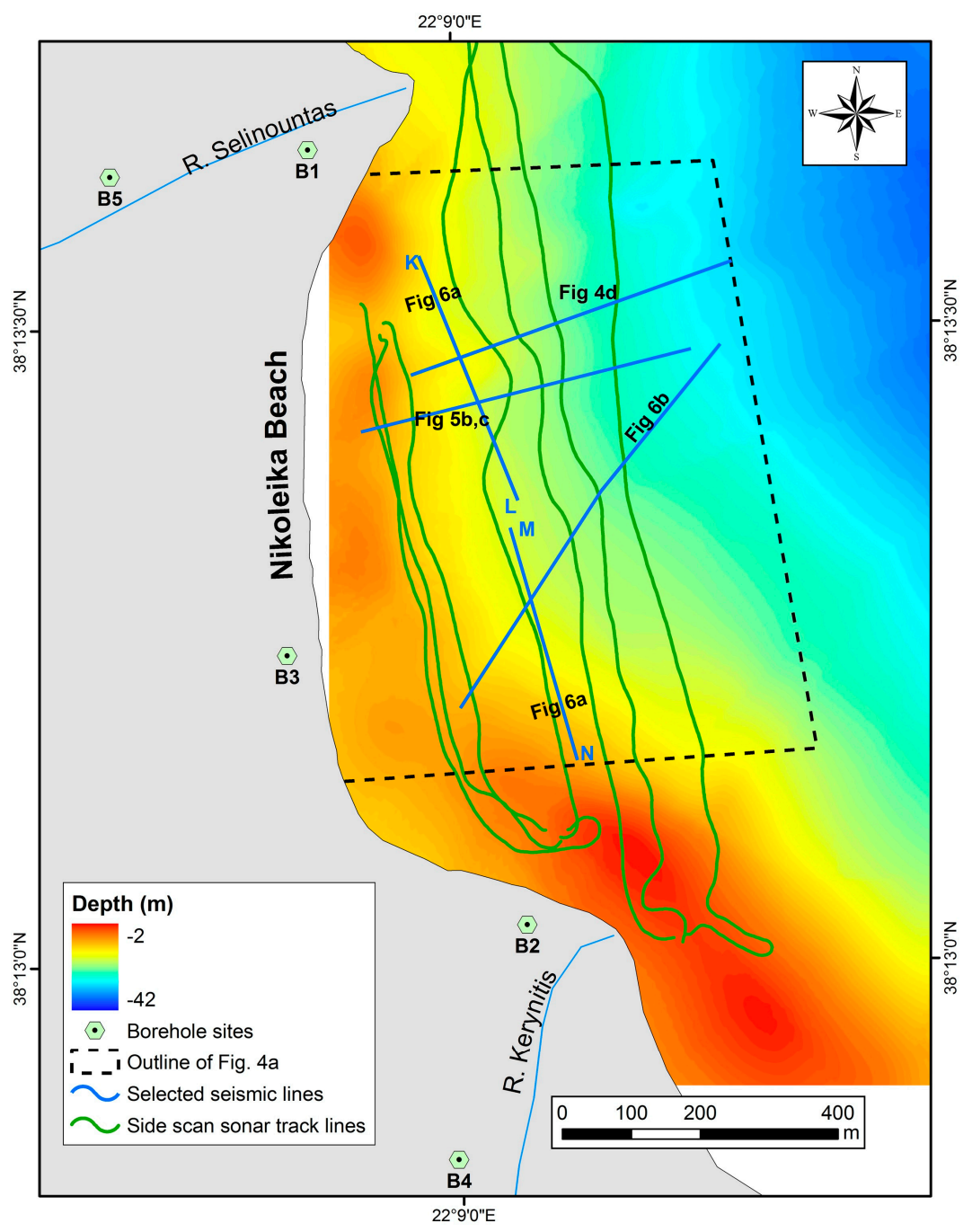

Figure 3. Bathymetric map of the delta front between the Selinountas and Kerynitis rivers, affected by the landslide, showing side scan sonar tracklines, selected $3.5 \mathrm{kHz}$ seismic profiler tracklines, and the borehole sites. 
The side scan sonar has been defined as an acoustic imaging device used to provide high-resolution 2D images of the seafloor. Side scan sonar produces an almost photo-realistic picture of the seabed and provides information on sediment texture and seafloor morphology based on backscatter [13]. The side scan sonar survey was conducted at an operating frequency of $100 \mathrm{kHz}$ and a range of $100 \mathrm{~m}$ per channel (swath width of $200 \mathrm{~m}$ ). Slant-range correction was applied to the side scan sonar data during survey. The lane spacing provided a 50\% range overlap. The towfish height above the seafloor ranged between $10 \%$ and $50 \%$ of the slant range. Side scan sonar data were processed using ISIS Sonar (Triton Elics) software and then were mosaicked with $0.5 \mathrm{~m}$ resolution using DelphMap (Triton Elics software). In the Helike survey, high backscatter, which is attributed to hard substrate and rough morphology, is presented by light tone on sonographs. Low backscatter is attributed to soft substrate and it is presented by dark tone.

A high frequency sub-bottom seismic profiler provides high-resolution images of the sub-bottom and the principles of this device are based on the seismic reflection method [14]. For the Helike survey, the sub-bottom profiler data were acquired using $3.5 \mathrm{kHz}$ frequency, a $1 \mathrm{~ms}$ pulse duration with a pulse rate of $10^{-1} \mathrm{~s}$. The vertical resolution of the system was about $0.5 \mathrm{~m}$, which is the minimum distance between the distinguishable reflectors.

\subsection{Geotechnical Survey}

The geotechnical conditions prevailing in the sedimentary cover along the coastal zone between the Selinountas and Kerynitis rivers were investigated by means of boreholes, between 25 and $35 \mathrm{~m}$ long, drilled onshore along the periphery of the head scarp zone (Figure 3). Standard penetration tests (SPT) were taken according to the British Standard, along the boreholes at intervals of about $2 \mathrm{~m}$ to measure the penetration resistance $(\mathrm{N})$ whilst Shelby tubes were used to determine the mechanical properties of the sediments required for slope stability and liquefaction susceptibility analyses.

Slope stability analysis, described in detail by Bromhead [15] and Fang [16], was evaluated using the infinite slope method. The morphology of the seafloor and the stratigraphy of the sedimentary column used in the analysis were taken from the study of the remote sensing data. The liquefaction potential analysis, described in detail by Idriss and Boulanger [17] and Lew and Tran [18], was evaluated based on the empirical correlations of in situ characteristics and observed field behavior of sediments during earthquakes as proposed by Seed et al. [19]. The horizontal acceleration induced by the $6.2 \mathrm{R}$ earthquake was estimated to range between 0.30 and $0.55 \mathrm{~g}$, depending on the local soil conditions [20].

\section{Geological Processes Potentially Responsible for the Destruction/Disappearance of Helike}

Geological processes capable of causing a disaster similar to that described for Helike are: (1) earthquakes and active faulting; (2) tsunamis; and (3) land subsidence caused by: (i) tectonic movement; (ii) soil settlement; and (iii) liquefaction and sliding.

Recent studies in the Corinth Gulf regarding the generation mechanism, occurrence and magnitude of the abovementioned hazards have shown that:

(1) The potential maximum expected earthquake magnitude is less than $6.7 \mathrm{R}[1,21]$ and the maximum expected seafloor displacement due to fault activation is between 1.1 to $1.3 \mathrm{~m}$, as the active faults length in the Gulf are less than $15 \mathrm{~km}[10,22]$. 
(2) The potential fault generated tsunami maximum wave height over the generation area, would be the same height as the seafloor displacement that is between 1.1 to $1.3 \mathrm{~m} \mathrm{[21].}$

(3) The seafloor in the Corinth Gulf is affected by three distinct morphological populations of submarine landslides, [23-25]: (i) Coastal and near-shore landslides, affecting active deltas associated with gentle slope gradient $\left(<2^{\circ}\right)$; (ii) coastal and near-shore landslides, affecting Gilbert type active deltas associated with steep slopes $\left(>16^{\circ}\right)$; and (iii) submarine landslides, affecting fault escarpments associated with steep slopes between $15^{\circ}$ and $20^{\circ}$. The former landslide type cannot generate a tsunami with a wave height capable of causing hazards because of: (i) the shallow water depth of the landslides mass center $(<15 \mathrm{~m})$; (ii) the inadequate thickness of the sliding mass $(<8 \mathrm{~m})$; and (iii) the short run out distance $(<300 \mathrm{~m})$. The two latter types of landslides could cause a tsunami with a wave height between 4 and $5 \mathrm{~m}$ [21]. This potential maximum expected wave height is in accordance with those reported in the tsunami catalogues for the Corinth Gulf. The largest tsunamis in the Corinth Gulf in the past had wave heights of between 2 and $5 \mathrm{~m}$, except for the one that occurred in 1748 and had a height of $10 \mathrm{~m}$ [26]. The largest of these tsunamis with wave heights of 5 and $10 \mathrm{~m}$ had an inundation distance of between 400 and $1200 \mathrm{~m}$, respectively [26].

(4) In the Helike delta plain soil/ground settlement is not expected to happen because it occurs only in dry granular (mainly sand) soil. In the Helike delta-plain, the soil is under-saturated or saturated as the water-table is between 1.0 and $1.5 \mathrm{~m}$ below surface all year round. However, for the sake of getting an approximation regarding magnitude settlement scale in dry soil, it is estimated, according to [27,28] that for a dry layer of $100 \mathrm{~m}$ in thickness, relative density of $60 \%$ and an average NSPT of 25 , it cannot exceed $60 \mathrm{~cm}$ following an earthquake of between 6 to $7 \mathrm{R}$ magnitude, acceleration $(\gamma) \mathrm{of} 0.25 \% \mathrm{~g}$ at ground surface and involving 10 equivalent uniform strain cycles.

(5) The surficial sediments (the top 15 to $20 \mathrm{~m}$ ) of the delta plains around the coastal zone in the Corinth Gulf are prone to liquefaction and sliding [5,25].

\section{Results and Discussion}

\subsection{Data Presentation}

A detailed marine remote sensing survey in the near shore zone between the Selinountas and Kerynitis rivers (Nikoleika beach), on which Helike was situated, have shown that after the $6.2 \mathrm{R}$ earthquake in 1995 the coastal and near-shore zone was affected by a landslide. The study of the side scan sonar data revealed five distinct acoustic backscatter patterns (Figures $4 \mathrm{a}$ and $5 \mathrm{a}$ ). The interpretation of those backscatter patterns together with the seismic profiling data have shown that each pattern may be attributed to a distinctive part or feature of the landslide: (i) a strong backscatter zone running parallel to the coastline represents the head scarp (Hs) of the landslide; (ii) an area of moderate reflectivity is attributed to the evacuation zone (Ez) of the landslide; (iii) narrow linear areas of high reflectivity accompanied with narrow zones of acoustic shadow (dark tone) ascribe to the compressional zone $(\mathrm{Cz})$ of the landslide; (iv) an extended uniform low-reflectivity area represents the undisturbed fine-grained sediments (Us) of the seafloor; and (v) localized strong backscatter facies in low reflectivity seafloor is attributed to the distal deposits (out-runners) (Or) of the landslide (Figures 4 and 5). 
The landslide had in plan-view an almost amphitheatrical shape extending parallel to the coastline, as is indicated by the spatial distribution of the backscatter patterns (Figures 4 and 5). The landslide had a width of $1200 \mathrm{~m}$ along the shoreline and a length of $600 \mathrm{~m}$ across it.

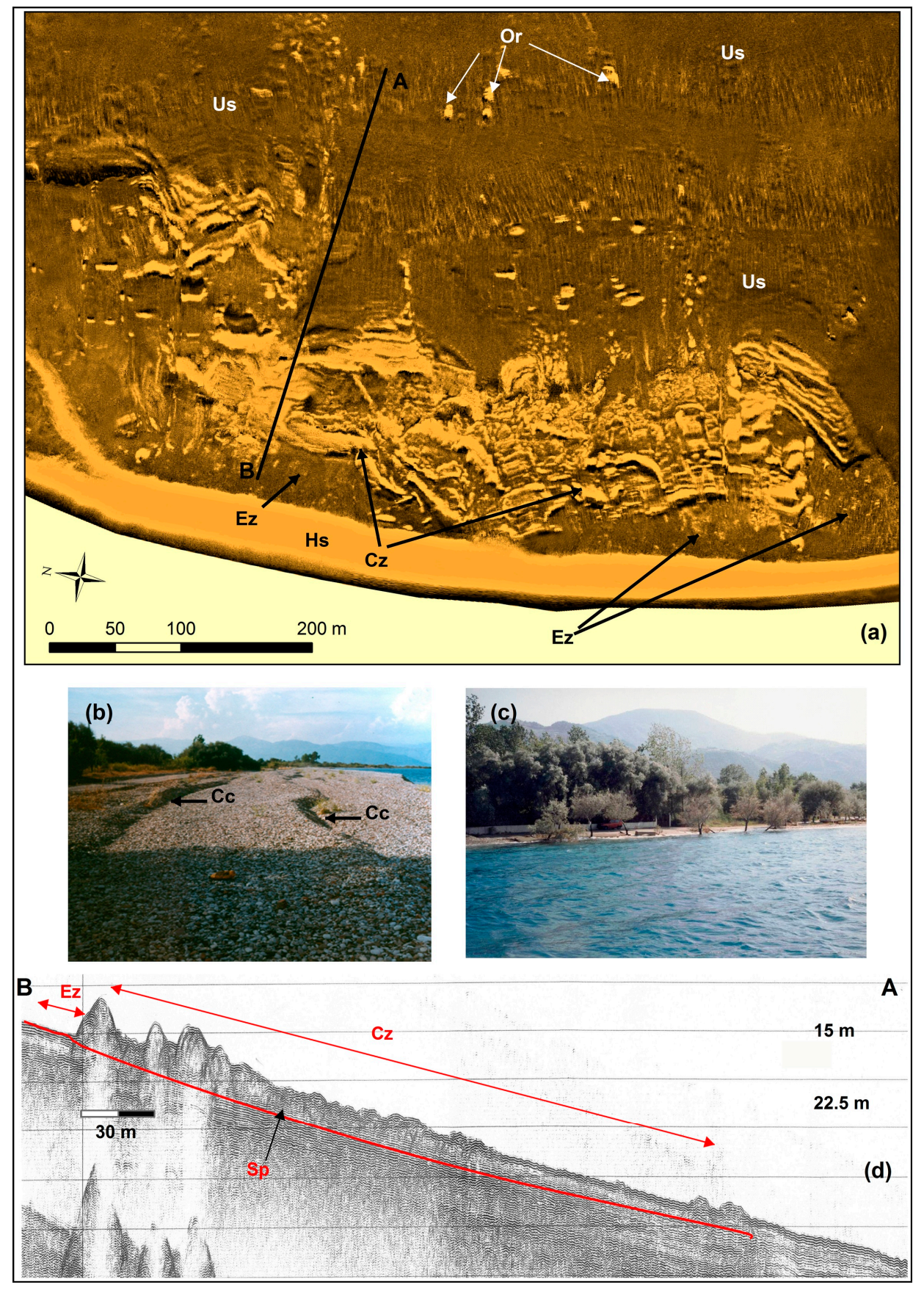

Figure 4. (a) Side scan sonar mosaic showing different backscatter acoustic patterns; (Hs): Head scarp, (Ez): Evacuation zone, (Cz): compressional zone, (Or): out-runners, (Us): Undisturbed sediments; (b,c) Photographs showing the slide crown and the associated en echelon fault rotated blocks (crown cracks-Cc), which affected the beach, and trees standing in the surf zone indicative for the submerged part of the beach, respectively, and (d) seismic profile across the coastal landslide showing (Ez): Evacuation zone, $(\mathrm{Cz})$ : compressional zone, (Sp): Slip plane. For the location of the mosaic and the profile see Figure 3. 


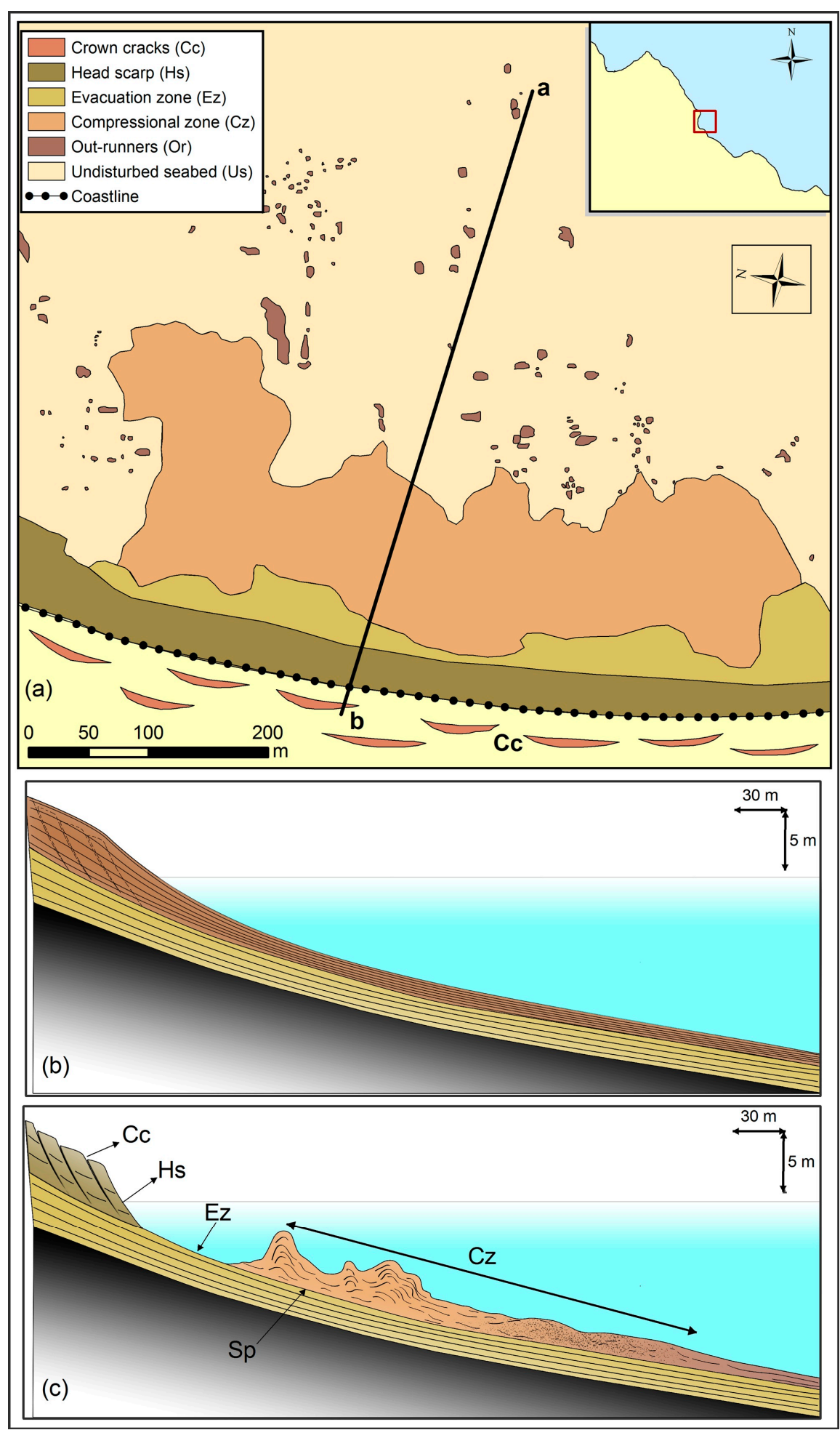

Figure 5. (a) Simplified schematic map of the coastal landslide showing the above mentioned features as interpreted from the sonar mosaic and seismic profiles; Sketch drawing showing a seabed profile before (b) and after (c) the 1995 earthquake. $(\mathrm{Cc})$ : Crown cracks, (Hs): Head scarp, $(\mathrm{Ez})$ : Evacuation zone, $(\mathrm{Cz})$ : compressional zone, (Sp): Slip plane. For the location of the profile ab see Figure 3.

The seismic reflection profiles in the dip direction show that the sliding took place over a single basal glide plane, about 3-5 $\mathrm{m}$ below the seafloor, which is also a bedding plane, dipping at about 
$0.5^{\circ}-1^{\circ}$ (Figure $4 \mathrm{~d}$ ). The seismic profiles together with backscatter acoustic patterns show that the slide can be divided into: (i) the head scarp zone; (ii) the evacuation zone; (iii) the compressional zone; and (iv) the distal deposits (Figure 5a).

The head scarp zone onshore is affected by shallow rotational slides as is indicated by the formation of rotated and landward tilted blocks, which are separated by scarps with a height of 0.5 to $1 \mathrm{~m}$ (Figures 4 and 5). The scarps were parallel to the shoreline and the blocks have dimensions of 10-15 $\mathrm{m}$ and 30-70 m perpendicular and parallel to the shoreline, respectively (Figure 5). Landward of the head scarp zone, ground cracks about $10 \mathrm{~m}$ long and $0.1 \mathrm{~m}$ wide were observed (Figure $4 \mathrm{~b}, \mathrm{c}$ ). Sand and water erupted from most of the cracks indicating that sediment liquefaction occurred in the deeper layers during the earthquake.

The slide plane/evacuation zone is related to one of the sub-bottom reflections and corresponds to a bedding plane within the stratified sedimentary sequence with an overall seaward dipping gradient of $0.5^{\circ}-1^{\circ}$ (Figures $4 a, d$ and 5 ).

The compressional zone in the upper part is characterized by high relief undulations with an elevation between 2 and $4 \mathrm{~m}$ corresponding to pressure ridges (Figures $4 \mathrm{a}, \mathrm{d}$ ), which developed perpendicular to the slide direction (Figure 4a). The internal acoustic character of the undulations indicates that the slid sediments have undergone a brittle deformation (Figure 4d). The lower part of the compressional zone is characterized by a low hummocky seafloor (Figure 4d). The internal acoustic character of the sediments underneath indicates that they have undergone plastic deformation during the transportation (Figure 4d).

The distal deposits are found mainly at the downslope end of the compressional zone, over undisturbed sediments (Figure 5a). They are individual sediment mounds less than $1 \mathrm{~m}$ high and about $5 \mathrm{~m}$ long. These are interpreted as glide blocks detached from leading margin of the slide.

Profiles in the strike direction show that the slid mass has a thickness less than $5 \mathrm{~m}$ and that within the slid body there are segments that have undergone different styles of deformation during transport, suggesting segmentation of the failed mass into linked discontinuous minor slides (Figure 6a). The above suggest that the landslide is a complex low-angle translation slide less than $5 \mathrm{~m}$ deep.

The seismic profiles show the presence of gas in the interstices of the sediments all over the Helike delta front, at depths more than $10 \mathrm{~m}$ below the seafloor, as is indicated by the acoustic turbid zone and gas plumes (Figure 6b). During the 1995 earthquake, due to the increase of the pore pressure in the sediments caused by the cyclic loading induced by the earthquake, gas and water emanated from the sediments and formed sand volcanoes in the seafloor (Figure 6b) [24].

The geotechnical study of the borehole data shows that the delta plain surficial cover is occupied by soft, mainly cohesionless and poorly sorted, deltaic deposits. In detail the subsurface sediments are separated into three general stratigraphic-geotechnical units (Figure 7).

Unit I consists of non cohesive silty sandy gravel with silty sand inter-layers characterized by medium to high relative density $(\mathrm{Dr}=5 \%-80 \%)$ and NSPT between 15 and 45 . The thickness of the unit ranges between 3 and $9.5 \mathrm{~m}$ (Figure 7).

Unit II consists of silty sands with a low percentage of gravelly and clayey sand. They are characterized by low to medium relative density $(20 \%-50 \%)$ and penetration resistance (NSPT) less than 20. The thickness of the unit ranges from 3 to $20 \mathrm{~m}$ (Figure 7). 

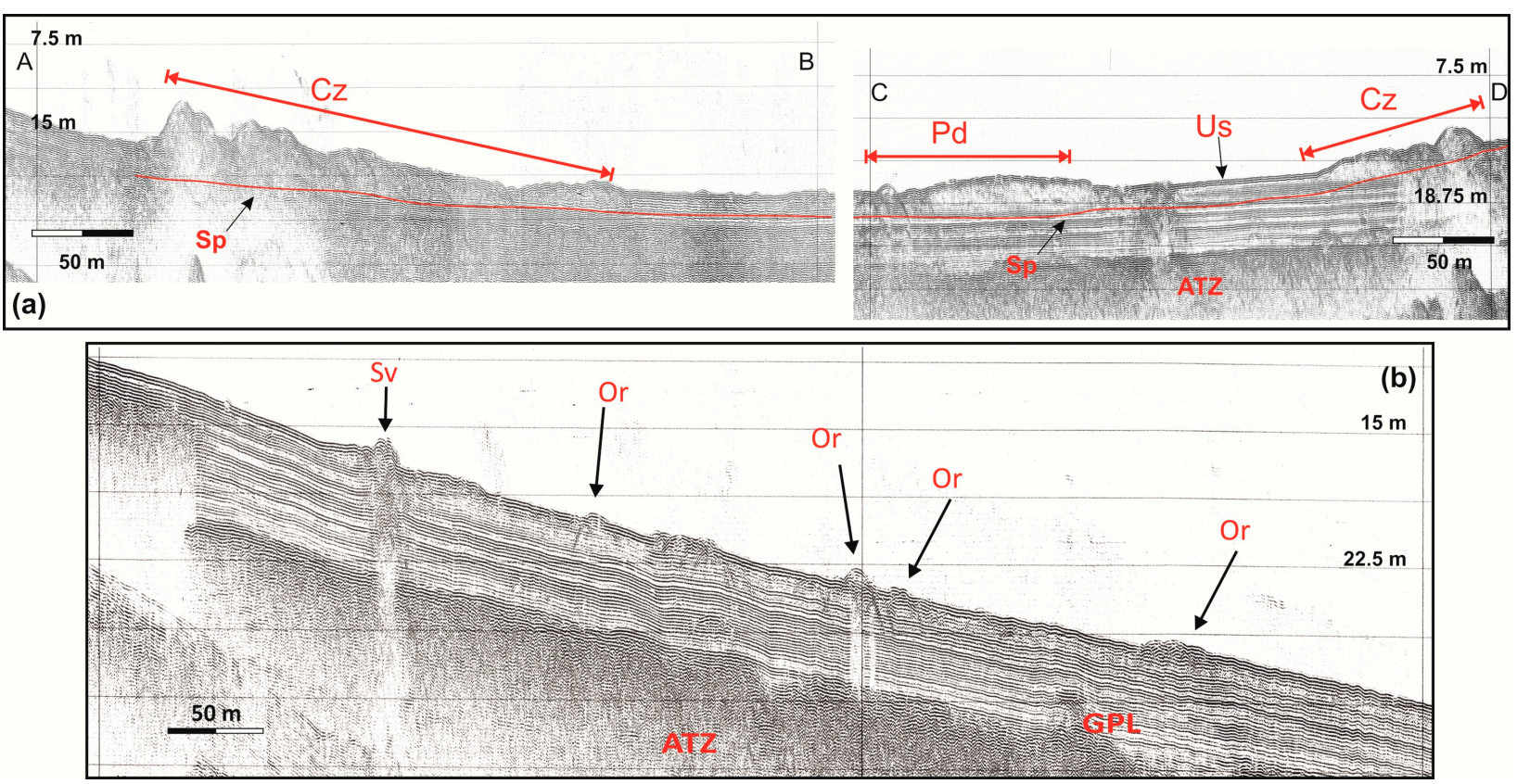

Figure 6. (a) Seismic profiles in the strike direction showing the slide plane all over the area and slid masses with different styles of deformation during transport; $(\mathrm{Cz})$ : compressional zone, (Pd): slide deposits that have undergone plastic deformation, (Us): undisturbed sediments, (Sp): Slip plane, (ATZ): Acoustic turbid zone; (b) Seismic profile in the dip direction showing the presence of gas below the surficial sediments as indicated by the acoustic turbid zone (ATZ) and gas plumes (GPL). The disruption of the stratified surficial reflections by piercement like feature indicate the presence of sand volcano (Sv) formed by the expulsion of water and gas induced by the earthquake. (Or): Out-runners. For the seismic profiles location see Figure 3.

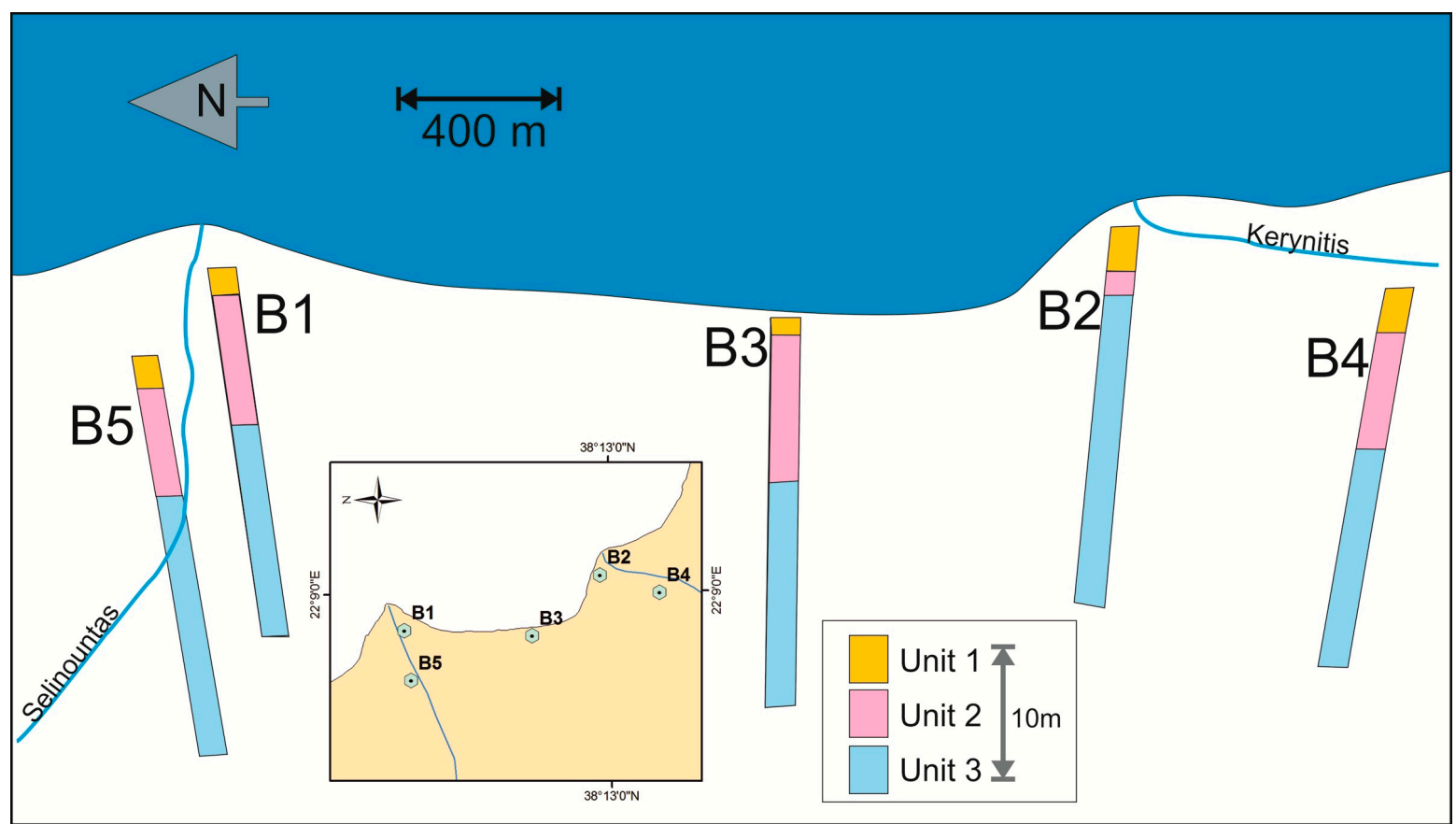

Figure 7. Three-dimensional representation of the three stratigraphic-geotechnical units recovered from the boreholes. 
Unit III is in depths more than $14 \mathrm{~m}$, it consists of medium plasticity sandy clays with silt inter layers. The low penetration resistance $\left(\mathrm{NSPT}_{2}<20\right)$ together with the relative high values of the unconfined compression strength (20-150 kPa) suggest medium stiff to stiff clay deposits (Figure 7).

The stability analysis (for more details see [15]) under undrained conditions revealed that the coastal/near-shore slope appears to be stable (Safety Factor $(\mathrm{SF})=1.50$ ) under condition of static gravitational load and marginally stable to stable (Safety Factor $(\mathrm{SF})=0.90-1.20)$ under the cyclic loading generated by $6.2 \mathrm{R}$ earthquake in 1995.

The liquefaction potential analysis showed: (i) the presence of liquefaction prone horizons at depths between 4.5 and $15 \mathrm{~m}$ having an estimated liquefaction potential (LP) between 0.2 and 0.8 ; and (ii) that for each test site the required seismic acceleration of between 0.20 and $0.50 \mathrm{~g}$ for the non-cohesive sediments of Unit II at depths between 4.5 and $15 \mathrm{~m}$ to be liquefied, was exceeded by the peak horizontal ground acceleration of between 0.30 and $0.55 \mathrm{~g}$ induced by the 1995 earthquake.

Based on the data presented above, it is postulated that the initiation mechanism responsible for the initiation of the landslide, is liquefaction of a shallow subsurface horizon. This mechanism is further supported by: (i) the extensive presence of sand and water eruption features during the 1861 [3,29] and 1995 earthquakes and (ii) the presence of gas in the sediments [24,30], which enhances the liquefaction processes.

\subsection{Discussion}

Geological processes similar to those described in the present study occurred over the same area after an earthquake of an estimated 6.6 R magnitude in December 1861 [1]. According to Julius Schmidt [3], who was the director of the Astronomical Institute in Greece, the earthquake opened a $13 \mathrm{~km}$ long and $2 \mathrm{~m}$ high crack along the base of the foothills, at what is now called the Helike fault. He also mentioned that at the same time numerous fissures, parallel to the shoreline, opened at the surface and sand erupted through them, forming "sand volcanoes" indicative of sediment liquefaction and that a small tsunami with a wave height of $2 \mathrm{~m}$ occurred. Furthermore, [3] reported that the entire delta plain north of the crack slowly subsided, submerging a coastal fringe $13 \mathrm{~km}$ long and $200 \mathrm{~m}$ wide (Figure 8 [31]). He also suggested that Helike was submerged due to a similar but a more violent event [3].

The above presented information regarding the generation mechanism of the coastal slide induced by the 1995 earthquake along with: (i) geological processes, which occurred over the same area after a 6.6 R magnitude earthquake in December 1861 (Schmidt 3, 31); (ii) the recent geoarchaeological findings about classical Helike [6,7]; and (iii) the sequence of events, which led to Helike's destruction as taken from historical sources, allow us to postulate the following geological process that caused the catastrophe of Helike:

(1) Helike was devastated by an earthquake of between 6 to $6.7 \mathrm{R}$ in magnitude. An earthquake of such a magnitude could have devastated any city at that time.

(2) Helike was most probably submerged by a slide of the same type as that which occurred during the 1995 earthquake (Figure 9). The slide would have had a width of about 1.5 to $2 \mathrm{~km}$, a length of between 1 and $2 \mathrm{~km}$ with the slide-crown parallel to the foothills and a thickness between 3 and $5 \mathrm{~m}$. (Figure 9). Such a slide would have resulted in the seawards transfer of the failed mass on which Helike stood and would have caused enough subsidence of the surface, 
up to $10 \mathrm{~m}$, in relation to the surrounding land, thus permitting the invasion of the sea over the sliding mass and the submergence of Helike for a long period of time.

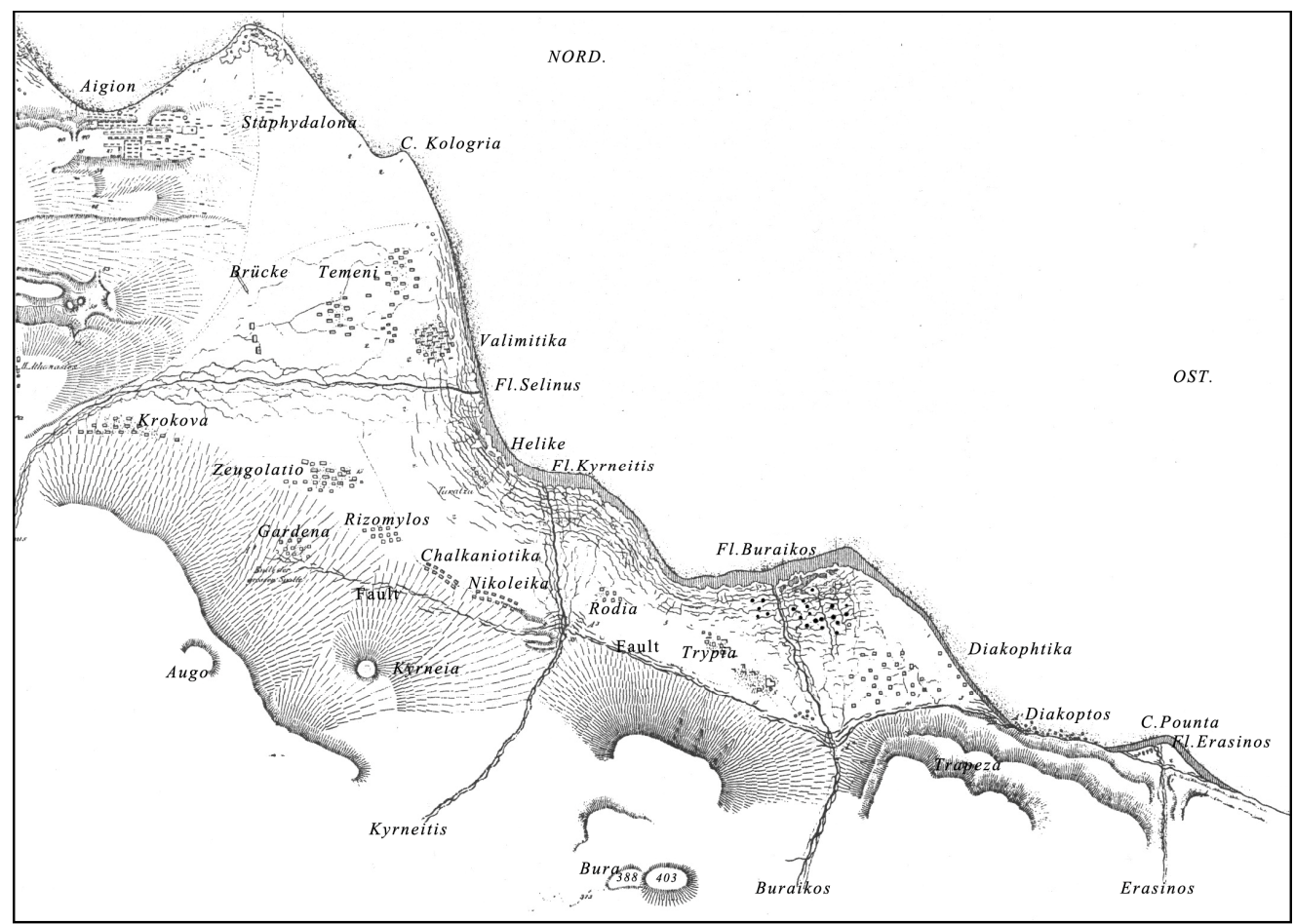

Figure 8. Reproduction of the original map of Schmidt's map of the Helike Delta, drawn a month after the earthquake of December 1861 [31]. A fault crack extends along the base of the hills from Pounta to Gardena (modern Keryneia). The shaded fringe by the shore represents the area submerged by the earthquake. Extensive fissuring occurred all along the shore, and sand volcanoes (solid circles) were concentrated on the delta of the Vouraikos River.

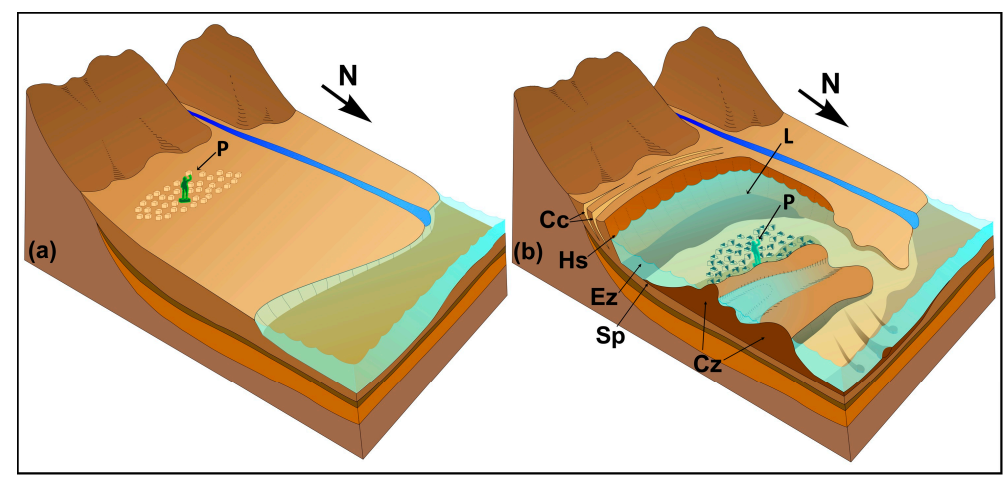

Figure 9. Three-dimensional sketch map, not in scale, of the landscape reconstruction of the delta plain where Helike was built before (a) and after (b) the translational slide, which affected the surficial sediments and caused the destruction and submergence of Helike. The translational slide in (b) has been enlarged more than that of the delta plain so that its geomorphological features are highlighted. (Cc): Crown cracks, $(\mathrm{Hs})$ : head of the slide, $(\mathrm{Ez})$ : evacuation zone, $(\mathrm{Cz})$ : compressional zone, $(\mathrm{Sp})$ : Slip plane and liquefaction horizon, $(\mathrm{P})$ : statue of Poseidon in upright position and (L): lagoon. 
This model for the devastation/disappearance of Helike agrees with that of: (a) Leonards et al. [5], who proposed that the catastrophe of Helike was caused either by soil liquefaction or landsliding, triggered by an earthquake; (b) Schmidt's [3,31] description of events that occurred during the 1861 earthquake; (c) the geoarchaeological findings of Soter and Katsonopoulou [7]; and (d) the description of events that caused the disappearance of Helike as given by Aelian and Strabo.

Soter and Katsonopoulou (2011) [7] depicted in their boreholes a clastic layer (their horizon C), which, based on its areal extent and its depth below surface, could have acted as a slip-plane for the postulated translational slide. A translational slide using as a sliding plane Soter's and Katsonopoulou's horizon $\mathrm{C}$ would have affected the foundation layer on which the Early Bronge Age (E.B.A) settlement lies. However, taking into consideration that: (i) within the 1995 translational slide were segments that were transferred as rigid bodies and (ii) the same could have happened during the 372/373 B.C. earthquake, then it can be concluded that the E.B.A settlement was transferred within the rigid segment without being disturbed. The seaward transport of the slide as a rigid body is supported by Strabo, who wrote that "there was a bronze statue of Poseidon in the straits standing in an up-right position".

Similarly, in the event that the postulated translational slide had occurred over a slip-plane between 3 and $4 \mathrm{~m}$ below surface, would not have affected the layer on which the E.B.A settlement was founded, thus leaving the structures of the settlement undisturbed.

An earthquake triggering a large tsunami, as suggested by Marinatos [4], cannot account for the disappearance of Helike. A tsunami would have flooded Helike temporarily and would have then retreated. Therefore, Helike would not have remained under water for 500 years. Furthermore, a tsunami would have covered the traces of Helike found with coarse marine sediments instead of fine lagoonal sediments. The tsunami wave height would have been of a much greater height than the maximum expected $(>5 \mathrm{~m})$ in order to invade the coastal zone $1 \mathrm{~km}$ inland and thus to flood Helike. Such a tsunami would have affected within 10 min a much wider area around the Corinth Gulf [20], thus affecting the harbors of other important ancient cities of that time, such as Corinth and Sikyon (Figure 1). However, such damage was not mentioned in any of the existing historical sources.

The submergence of Helike could not have been caused, either, by the activation of the Helike fault as suggested by Soter and Katsonopoulou [6] because such a displacement would have been between 1.1 and $1.3 \mathrm{~m}$ and could not have caused enough subsidence in the coastal zone for the city to have been permanently submerged. Moreover, there is not any evidence that the Helike fault was activated at that time [8]. This suggests that the earthquake responsible for the devastation of Helike was caused by the activation of another of the numerous faults in the Corinth Gulf.

The proposed earthquake model and the related translational slide as the natural forces behind the Helike catastrophe, based on the analysis of the slide, which affected the coastal and near-shore zone after the 6.2 R earthquake in 1995, appear to be better founded than those proposed by Marinatos [4], Soter and Katsonopoulou [7], and Soter et al. [11].

\section{Conclusions}

A marine remote sensing survey accompanied by on shore borehole data, to examine the causes, which triggered a coastal slide following the $6.2 \mathrm{R}$ earthquake in 1995, that affected the nearshore delta plain zone on which classical Helike stood, has enabled us to postulate the potential geological processes 
behind the disappearance of Helike from the earth's surface in 373/372 B.C. Helike was initially devastated by an earthquake of between 6 and $6.7 \mathrm{R}$ in magnitude and then it submerged following a shallow translational slide caused by liquefaction of the same type as that which occurred during the 1995 earthquake.

The proposed earthquake and associated translational slide model as the natural force behind the Helike catastrophe is consistent with current views regarding the expected geological magnitudinal hazards in the Gulf of Corinth, the recent geoarchaeological findings on Helike and the sequence of events leading to Helike's destruction as described in historical sources.

The proposed model in the present study appears to be better founded than those suggested in the past, which stated as potential geological hazards for the destruction of Helike, either an earthquake followed by a tsunami or an earthquake and the associated 3 to $5 \mathrm{~m}$ subsidence of the hanging wall in conjunction with a powerful tsunami.

\section{Acknowledgment}

The authors would like to thank the anonymous reviewers for their constructing remarks.

\section{Author Contributions}

All authors have contributed equally to this work

\section{Conflicts of Interest}

The authors declare no conflict of interest.

\section{References}

1. Ambraseys, N.N.; Jackson, J. Seismicity and associated strain of central Greece between 1980 and 1988. Geophys. J. Int. 1990, 101, 663-708.

2. Katsonopoulou, D. The earthquake of 373 B.C. literary and archaeological evidence. In Helike III, Archaeological Sites in Geologically Active Regions; Katsonopoulou, D., Soter, S., Koukouvelas, I., Eds.; The Helike Society: Athens, Greece, 2005; pp 15-31.

3. Schmidt, J. Sur le grand treblement de terre qui a en lieu en Grece le 26 Decembre 1861. CR Hebd. Seances Acad. Sci. 1862, 54, 669-671.

4. Marinatos, S. Helice: A submerged town of Classical Greece. Archaeology 1960, 13, 186-193.

5. Leonards, G.; Sotiropoulos, E.; Kavvada, M. Helice: The lost town of ancient Greece. In Engineering Geology of Ancient Works Monuments and Historical Sites; Marinos, P.G., Koukis, G.C., Eds.; Balkema: Rotterdam, The Netherlands, 1988; pp. 1307-1313.

6. Soter, S.; Katsonopoulou, D. Occupation horizons found in the search for the ancient Greek city of Helice. Geoarchaeology 1999, 14, 531-563.

7. Soter, S.; Katsonopoulou, D. Submergence and uplift of settlements in the area of Helike, Greece, from the Early Bronze Age to late antiquity. Geoarchaeology 2011, 26, 584-610.

8. Chatzipetros, A.; Kokkalas, S.; Pavlides. S.; Koukouvelas, J. Palaioseismic data and their implication for the active deformation in Greece. J. Geodyn. 2005, 40, 170-188. 
9. Bell, R.E.; McNeill, L.; Bull, J.M.; Henstock, T.J. Evolution of the offshore western Gulf of Corinth. Geol. Soc. Am. Bull. 2008, 120, 156-178.

10. Stefatos, A.; Papatheodorou, G.; Ferentinos, G.; Leeder, M.; Collier, R. Seismic reflection imaging of active offshore faults in the Gulf of Corinth: Their seismotectonic significance. Basin Res. 2002, 14, 487-502.

11. Soter, S.; Blackwelder, P.L.; Tziavos, C.; Katsonopoulou, D.; Hood, T.; Alvarez-Zarikian, C.A. Environmental analysis of cores from the Helike Delta, Gulf of Corinth, Greece. J. Coast. Res. 2001, 17, 95-106.

12. Alvarez-Zarikian, C.A.; Soter, S.; Katsonopoulou, D. Recurrent submergence and uplift in the area of ancient Helike, Gulf of Corinth, Greece: Microfaunal and archaeological evidence. J. Coast. Res. 2008, 24, 110-125.

13. Blondel, P. Handbook of Sidescan Sonar; Springer-Praxis: New York, NY, USA, 2009.

14. Trabant, P.K. Applied High-Resolution Geophysical Methods Offshore Geoengineering Hazards; D. Reidel Publishing Company: Boston, MA, USA, 1984; p. 265.

15. Bromhead, E. The Stability of Slopes; Surrey University Press: New York, NY, USA, 1986.

16. Fang, H. Foundation Engineering Handbook; Klewer Academic Publishers Group: Massachusetts, MA, USA, 2002; p. 614.

17. Idriss, I.M.; Boulanger, R.W. Spt-Based Liquefaction Triggering Procedures; Report No. UCD/CGM10/021; University of California at Davis: Davis, CA, USA, 2003.

18. Lew, M.; Tran, L. Case history of observed liquefaction-induced settlement versus predicted settlement. In Proceedings of the 15 World Conference on Earthquake Engineering, Lisbon, Portugal, 24-28 September 2012.

19. Seed, B.; Tokimatsu, K.; Harder, L.; Chung, R. Influence of SPT procedures in soil liquefaction resistance evaluations. ASCE J. Geotech. Eng. 1985, 111, 1425-1445.

20. Bouckovalas, G. Analysis of Earthquake Induced Ground Failures along the Eratini-Tolofon Eroding Coast; Technical Report; Hellenic Ministry of Environment, Planning and Public Works: Athens, Greece, 1998.

21. Stefatos, A.; Charalambakis, M.; Papatheodorou, G.; Ferentinos, G. Tsunamigenic sources in an active European half-Graben (Gulf of Corinth, Central Greece). Mar. Geol. 2006, 232, 35-47.

22. Zygouri, V.; Verroios, S.; Kokkalas, S.; Xypolias, P.; Koukouvelas, I.K. Scaling properties within the Gulf of Corinth, Greece; comparison between offshore and onshore active faults. Tectonophysics 2008, 453, 193-210.

23. Papatheodorou, G.; Ferentinos, G. Sedimentation processes and basin filling depositional architecture in an active asymmetric graben: Strava graben, Gulf of Corinth, Greece. Basin Res. 1993, 5, 235-253.

24. Papatheodorou, G.; Ferentinos, G. Submarine and coastal sediment failure triggered by the 1995 $\mathrm{Ms}=6.1 \mathrm{R}$ Aegion earthquake, Gulf of Corinth, Greece. Mar. Geol. 1997, 137, 287-304.

25. Hasiotis, T.; Papatheodorou, G.; Boukovalas, G.; Corbau, C.; Ferentinos, G. Earthquake-induced coastal sediment instabilities in the western Gulf of Corinth, Greece. Mar. Geol. 2002, 186, 319-355.

26. Papadopoulos, G. Tsunami hazard in the eastern Mediterranean: Strong earthquakes and Tsunamis in the Corinth Gulf, Central Greece. Nat. Hazards 2003, 29, 437-464.

27. Tokimatsu, K.; Seed, H.B. Evaluation of settlements in sands due to earthquake shaking. J. Geotech. Eng. 1987, 113, 861-878. 
28. Chen, Y.R.; Hsieh, S.C.; Chen, J.W.; Lee, C.Y. Evaluation of earthquake-induced settlement in dry sand layers. Electron. J. Geotech. Eng. 2009, 14, 1-19.

29. McNeill, L.C.; Collier, R.E.L.; de Martini, P.; Pantosti, D.; D’Addezio, G. Recent history of the Eastern Eliki Fault, Gulf of Corinth: Geomorphology, palaeoseismology and impact on palaeoenvironments. Geophys. J. Int. 2005, 161, 154-166.

30. Soter, S. Macroscopic seismic anomalies and submarine pockmarks in the Corinth-Patras rift, Greece. Tectonophysics 1999, 308, 275-290.

31. Schmidt, J. Studien uber Erdbeben; Scholtze: Leipzig, Germany, 1875.

(C) 2015 by the authors; licensee MDPI, Basel, Switzerland. This article is an open access article distributed under the terms and conditions of the Creative Commons Attribution license (http://creativecommons.org/licenses/by/4.0/). 